\title{
SOLUTION TO URBAN AIR POLLUTION - CARBON FREE TRANSPORT
}

\author{
Jānis KLEPERIS ${ }^{1}$, Biruta SLOKA ${ }^{2}$, Justs DIMANTS ${ }^{3}$, \\ Ilze DIMANTA ${ }^{4}$, Jānis KLEPERIS Jr. ${ }^{5}$ \\ ${ }^{1-5}$ University of Latvia, Latvia \\ Corresponding author e-mail: Biruta.Sloka@lu.lv
}

\begin{abstract}
The analysis of the results of long-term air quality monitoring in Riga is presented, which shows that in city centre throughout the measurement time (2004-2014) according to the guidelines defined by the European Union directives and Latvian laws the limits of small particles $\mathrm{PM}_{10}$ and nitrogen dioxide $\left(\mathrm{NO}_{2}\right)$ are exceeded. From the nature of appearance of pollution and from the research of morphology and composition of fine dust particles it was concluded that in the city centre where the monitoring was performed the main air pollutants are caused by internal combustion engine vehicles. The measures to reduce air pollution performed by two Action Programs (2004-2009; 20112015) of the City Council showed that there were only two possible ways to improve air quality in urban environment - to decrease the number of traffic units and/or to decrease exhaust emissions from vehicles.

From the analysis of energy consumption and resources used for it the conclusion was drawn that Latvia is dependent on fossil fuel import, especially in traffic sector (99\%). A new trend has been observed in Latvia - the type of cars is changing: the number of gasoline cars rapidly decreases and number of diesel cars is growing. Both fuels in exhaust gases of second-hand cars are giving high emissions of fine particles (soot) and nitrogen oxides as compared with new cars; $72 \%$ of cars on the roads of Latvia are more than 13 years old. The switch to bio-diesel can improve Latvian statistics according to $\mathrm{CO}_{2}$ reduction target for 2020 but not the concentration of $\mathrm{PM}_{10}$ and $\mathrm{NO}_{2}$ on streets with dense traffic. Therefore, to improve air quality in urban environment and simultaneously reduce the dependence of Latvia from fossil fuel import, a scenario is proposed for the changeover to zero-carbon technologies in transport and energy production. Hydrogen is analyzed from the point of view of availability of resources and commercialized technologies. The research of the public opinion was done because there is little awareness in society about hydrogen as energy carrier and simultaneously as fuel.
\end{abstract}

Keywords: Attitude, hydrogen economy, public opinion, transport emissions, urban air pollution.

\section{INTRODUCTION}

More than half of the world's population nowadays is living in large cities, and urban environment badly affects the health of their population. One of the main urban conditions that damage the health of the population is the polluted air due to high concentration of emissions from internal combustion engines of different 
vehicles and industrial enterprises. Among the air pollutants particulate matter was found to be the most damaging. Particulates include dust, dirt, soot, smoke, and liquid droplets directly emitted into atmosphere by sources such as factories, power plants, vehicle exhausts, construction activity, fires, and windblown dust. They are also formed in the atmosphere by condensation of emitted gases such as sulfur dioxide, nitrogen oxides, and volatile organic compounds into tiny droplets. These particles affect health as they are able to penetrate deep into the sensitive regions (thoracic or lower regions) of the respiratory tract. Recent studies on the effects of chronic exposure to air pollution have identified $\mathrm{PM}_{10}$ as the pollutant most responsible for the life-shortening effect of dirty air (Near Roadway Air Pollution, n.d.). The major concerns for human health include effects on breathing and respiratory symptoms, aggravation of existing respiratory and cardiovascular disease, alterations in the body's defense systems against foreign materials, damage to lung tissue, carcinogenesis and premature death (Zhang et al., 2009). Another important air polluter from vehicle exhausts and boiler stacks is nitrogen dioxide $\mathrm{NO}_{2}$. Nitrogen is not in the composition of fuels, but it is in the air, and for combustion processes the fuel is mixed with air, and when the combustion temperature exceeds $600{ }^{\circ} \mathrm{C}$, the nitrogen oxides are produced. Nitrogen dioxide in the atmosphere causes acid rain, and inhaled in higher concentrations damages health (Zhang et al., 2009).

Due to non-compliance with air quality standards, Latvia has received the European Commission's formal notifications of the infringement procedure (2010, 2013) which state that the reports on air quality assessment in 2007, 2008 and 2010 submitted by the Republic of Latvia show that the agglomeration of Riga has exceeded the limits set by the Directives of the European Parliament and the European Council on Ambient Air Quality and Cleaner Air for Europe. The limits for human health of particle $\mathrm{PM}_{10}$ concentrations in air are as follows: annual limit value is $40 \mu \mathrm{g} / \mathrm{m}^{3}$ and the exceedances of daily concentration above $50 \mu \mathrm{g} / \mathrm{m}^{3}$ no more than 35 times per calendar year.

To reach better living standards in urban environment, it is necessary to switch to low-carbon society with low or zero emissions vehicles, low-energy and lowemission buildings with intelligent heating and cooling systems (EU Roadmap, 2011). Many of these technologies are commercialized today and are introduced in the developed countries step by step, mostly as demonstration projects. Zero emission technologies in transport and stationary energy supply are tightly connected with hydrogen. If hydrogen is the fuel for the Sun, why cannot it be the fuel for us on Earth? Hydrogen is a very simple element, but at the same time it is very powerful. Hydrogen in catalytic and conventional combustion processes does not disappear when taken from water - the combustion in the atmosphere with oxygen again gives water (Hoffmann, 2012). Hydrogen-oxygen cycle is fully reversible and environment friendly, especially, if energy for water splitting is taken from renewables (sun, wind, hydropower, etc.). With the help of hydrogen and fuel cell it is possible to extend the range of electric vehicles, produce cleaner energy, as well as get the solution for storage and smooth usage of renewable energy recourses, decentralization of energy supply. It is important and necessary because burning of fossil fuels is polluting the environment, the price of fossil energy 
resources is growing, and accidents in centralized energy supply networks are happening more often.

Attention to hydrogen as energy source for public transport has been discussed world-wide (Hoffmann, 2012) and analysis of different experience has been evaluated (Reijalt, 2010; Tarigan \& Bayer, 2012; Ahmed et al., 2015; Cruz and Katz-Gerro, 2015; Singh et al., 2015). In Latvia scientists pay significant attention to energy planning and managing problems (Actina et al., 2015; Geipele et al., 2014; Geipele et al., 2015). Department of Energy (USA) concludes that current knowledge and awareness levels of hydrogen and fuel cells are still low in the general public, and misunderstandings of hydrogen properties continue to impart negative opinions about the safe use of hydrogen as a fuel (U.S. Department of Energy, 2012). Research on different aspects of hydrogen and fuel cell education in Europe has been performed by several authors and published in several research results; a lot of attention to education aspects is devoted by M. Reijalt (Reijalt, 2010). M. Ricci, P. Bellaby and R. Flynn for many years devoted their research to public knowledge and perceptions, as well as acceptance of hydrogen and the public involvement on paths to sustainable energy (Ricci et al., 2010). Research results in several countries on social acceptance of hydrogen energy concluded that more information and society education is needed (Wüstenhagen et al., 2007). Many applications of hydrogen energy in Norway took place in recent years, for example, opening of the Hydrogen Way from Oslo to Bergen, also research on public attitude is made (Tarigan \& Bayer, 2012).

The aim of the article is to tie together consequences (air pollution) with causes (traffic) and show the ways to eliminate the consequences (switch to zero emission cars). The authors are representing an inter-disciplinary team, therefore methods applied to implement the idea are taken by each member from his specific domain. The authors want to make the reader to understand that fossil fuel is not the only one in the world to move the car forward, and that the combustion of fuel in engine has a history - today's transport must be free of harmful exhaust gases.

\section{METHODOLOGY}

Traffic intensity calculations are performed regularly in Riga, the capital of Latvia, by using radar, magnetic loops and traditional human-based counting methods (Kleperis et al., 2002; 2007; 2011). To assess the level of air pollution in Riga, most important air pollutants are monitored by the City Council (canyon-type streets with dense traffic flow and industrial regions close to populated places in the city). Background pollution in Riga is monitored at national level (Ministry of Transport Republic of Latvia, 2010; EU Roadmap, 2011; Kleperis, 2007).

An air quality management system AIRVIRO and ENVIMAN is used for an inventory of air pollution sources in Riga and their related dispersion calculations (from 1994). Air monitoring systems based on differential optical absorption spectroscopy (DOAS) with open-air light beam 300-650 m are used to measure air quality on the background level, as well as on the street level in Riga (Kleperis et al., 2002; 2007; 2011; Ādamsone and Parupa, 2007). 
Air monitoring targets and thresholds are defined in regulations (LR Cabinet of Ministers, 2009) and are harmonized with European Union Directives (1999/30/EC and 2008/50/EC) on air quality.

To evaluate particle concentrations in the city centre three different measuring instruments have been used located within a short distance (300-500 m): Thermo ESM Andersen FH 62I-R measures $\mathrm{PM}_{10}$ concentrations at $18 \mathrm{Kr}$. Valdemāra Street, SM200 ADAM (Atmospheric Dust Automatic Monitor, Opsis AB) measures $\mathrm{PM}_{10}$ and $\mathrm{PM}_{2.5}$ concentrations at 73 Brīvības Street (canyon-type street with dense traffic) and 4 Kronvalda Blvd. (background station), and Grim Environmental Dust Monitor EDM 165 measures $\mathrm{PM}_{10}, \mathrm{PM}_{2.5}$ and $\mathrm{PM}_{1.0}$ concentrations at $48 \mathrm{Kr}$. Valdemāra Street (Air Quality Monitoring Station of Faculty of Chemistry of University of Latvia).

Generally accepted qualitative and quantitative economic research methods have been applied in this study to evaluate air pollution by days, seasons, years and sources, as well as pollutant emissions declared in statistics databases, energy consumption by sectors and fuels and public awareness. In general these were methods of analysis and synthesis for studying problems and processes in order to set the necessary stages of activities; questionnaires for different groups of society were developed (Actina et al., 2015; Kleperis et al., 2011; Steinberga et al., 2013; Sloka et al., 2014; Geipele et al., 2015).

\section{AIR POLUTION IN RIGA, CAPITAL OF LATVIA}

Riga is the largest city in Latvia with high economic activity - industry, construction, sea port and dense traffic flow. Various air pollutants (nitrogen oxides, sulfur oxides, hydrocarbons, particulates, etc.) are emitted into the atmosphere from traffic and boiler stacks (including households), industrial and cargo transshipment activities. The polluted air negatively affects both human health and the environment. Good air quality in urban environment is an important issue for sustainable city development and prosperity of the population.

Motor transport is the main polluter in the streets with dense traffic, and most affected is the closest neighborhood close to the ground surface where the total amount of pollution emitted by road transport is remarkably higher than the emission by stationary sources. The peculiarity of this type of pollution is that it is emitted near to the ground, and its dispersion is hindered by the dense buildings along the street sides. For this reason, the same amount of emitted substances of pollution creates much higher concentrations in the immediate vicinity at ground level (with impact on people) than emissions from industries (via chimneys). Inventory results for 1990-2012 show that traffic on the streets of Riga is responsible for $60-80 \%$ of all nitrogen oxides, $50-78 \%$ of all CO, $40-80 \%$ of all $\mathrm{PM}_{10}$ and $30-68 \%$ of all volatile organic compound emissions in Riga (Kleperis et al., 2002; 2007; 2011), (Steinberga et al., 2013). Calculated dispersion concentrations coincide quite well with directly measured values primarily on main streets with intense traffic. As it can be seen from total $\mathrm{CO}_{2}$ emissions during the period 1990-2014 (Fig. 1), they have reduced by 46 \% in Riga due transformation 
of economics, but what is important - the share of the transport sector has increased from $14 \%$ in 1990 to 38 \% in 2013 (Riga Energy Agency, 2014).

Within the period of 2007-2014, the $\mathrm{PM}_{10}$ concentrations in Riga exceeded the limits set by the guidelines - the annual average concentration of $40 \mu \mathrm{g} / \mathrm{m}^{3}$ only on the densely congested traffic streets - Brīvības and Kr. Valdemāra Street, while the city background was well below the threshold value (Fig. 2) (Ministry of Transport Republic of Latvia, 2010), (EU Roadmap, 2011), (Steinberga et al., 2013).

While the overall tendency of yearly background PM concentrations show a decreasing trend during last few years, the $\mathrm{PM}_{10}$ concentration levels at street canyons show an opposite tendency (Steinberga et al., 2013). Similar tendency has been observed in the case of $\mathrm{PM}_{10}$ daily value exceedances; for 2 years number of exceedances on urban street level grows quite rapidly and in 2013 reaches an extremely high number.

Such dramatic tendency could not be explained by meteorological phenomena, because no growing of number of exceedances was found at the background level. Some comparative analysis of size/mass, composition/morphology and long-term conventional PM measurements of apportionment of PM pollution levels show that black carbon emissions and resuspension from vehicles on streets are the cause of high PM pollution (Steinberga et al., 2013). New guidelines on smaller fraction $\mathrm{PM}_{2.5}$ of particulate matter have been applied from 1 January 2015 to further protect citizens from harmful pollutants in the air. The standards set for annual average concentration of $\mathrm{PM}_{2.5}\left(25 \mu \mathrm{g} / \mathrm{m}^{3}\right)$ are exceeded in Riga streets with dense traffic (Fig. 2, data from Brīvības Street, 2008-2010), and are low in background monitoring station 2011-2015.

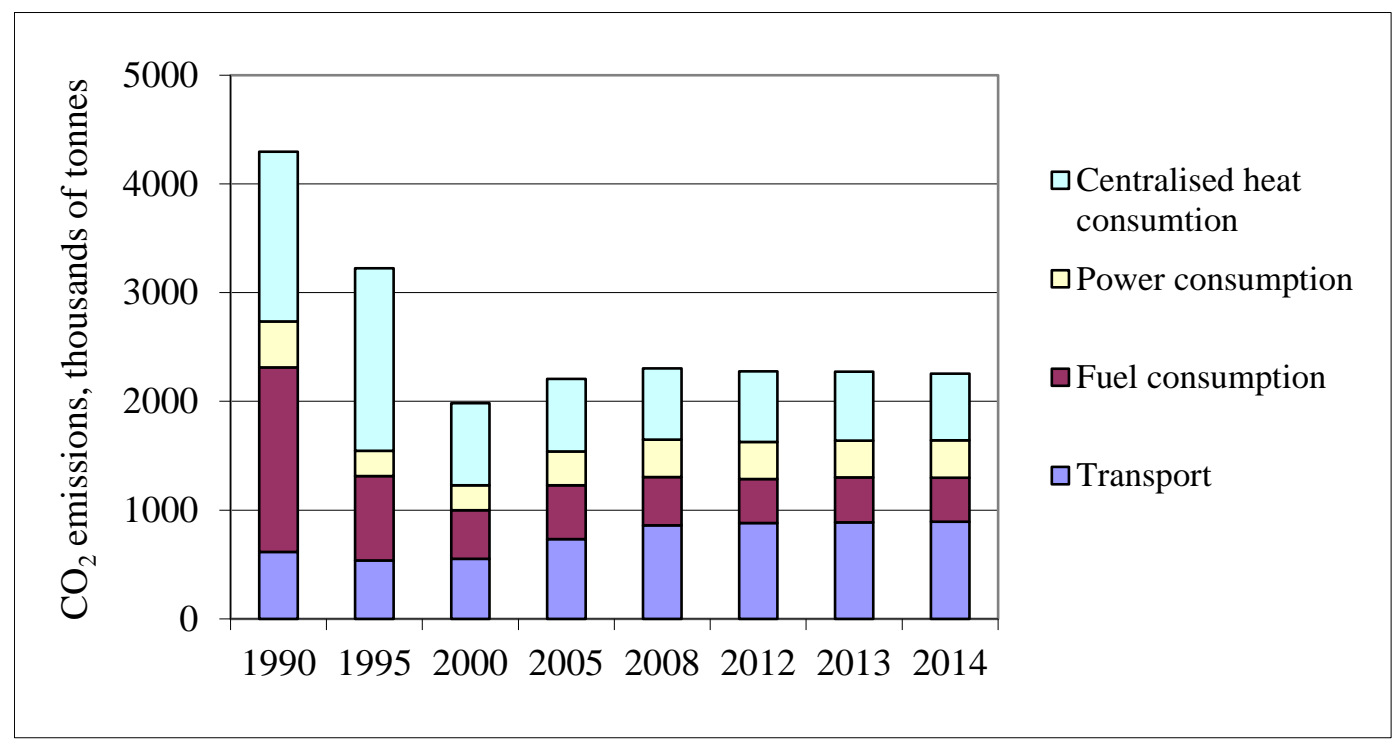

Fig. 1. $\mathrm{CO}_{2}$ emissions calculated by sectors in thousands of tonnes of $\mathrm{CO}_{2}$ equivalents (compiled by author from data of Riga City). 


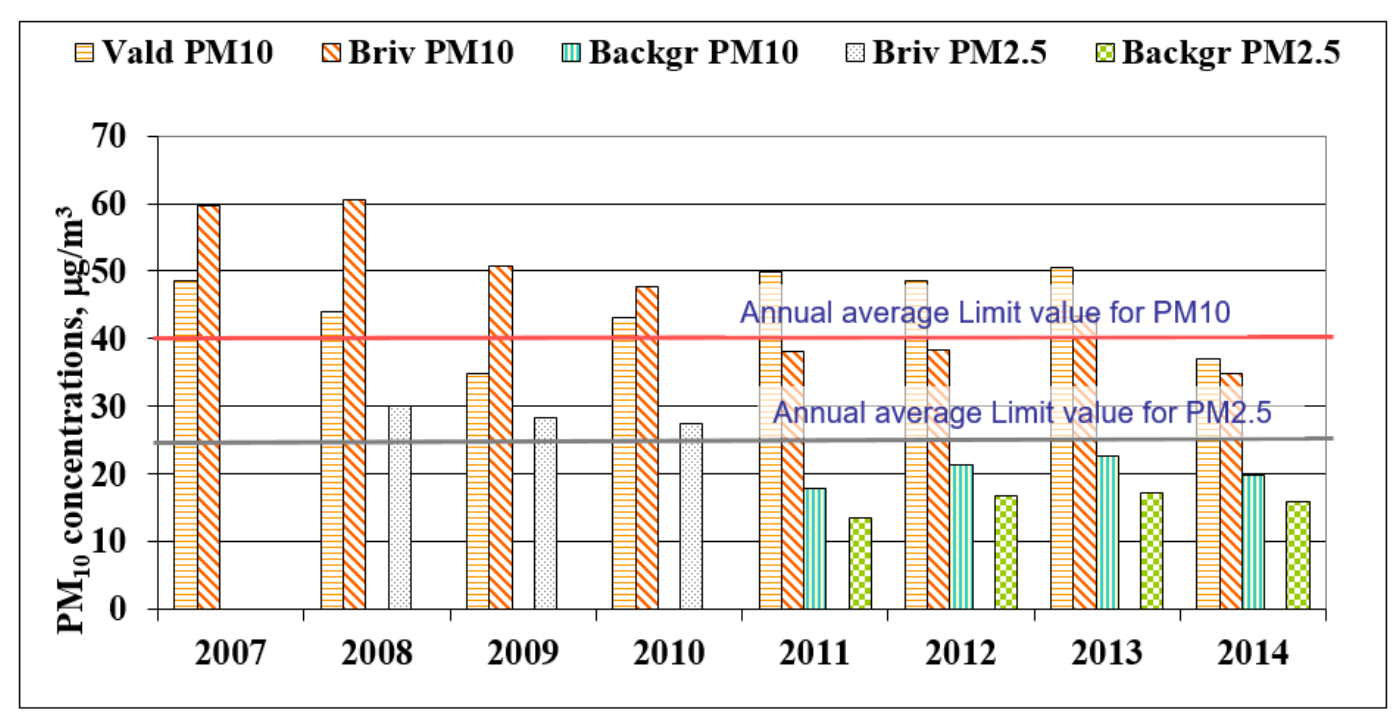

Fig. 2. PM annual concentration changes at street and urban background level in Riga, 2007-2014.

In assessing the contribution of separate transport groups in emissions of $\mathrm{NO}_{x}$ and $\mathrm{PM}_{10}$ in the city centre streets, it was found that light passenger cars are in the first place, then comes public transport and buses. This means that the replacement of internal combustion engines of Euro III class by higher and finally by electric/hydrogen vehicles will result in substantial improvement of $\mathrm{NO}_{x}, \mathrm{PM}$ and other emission from traffic in city centre streets (see Fig. 3. Calculation results of $\mathrm{NO}_{2}$ emissions from passenger cars for one street in Riga).

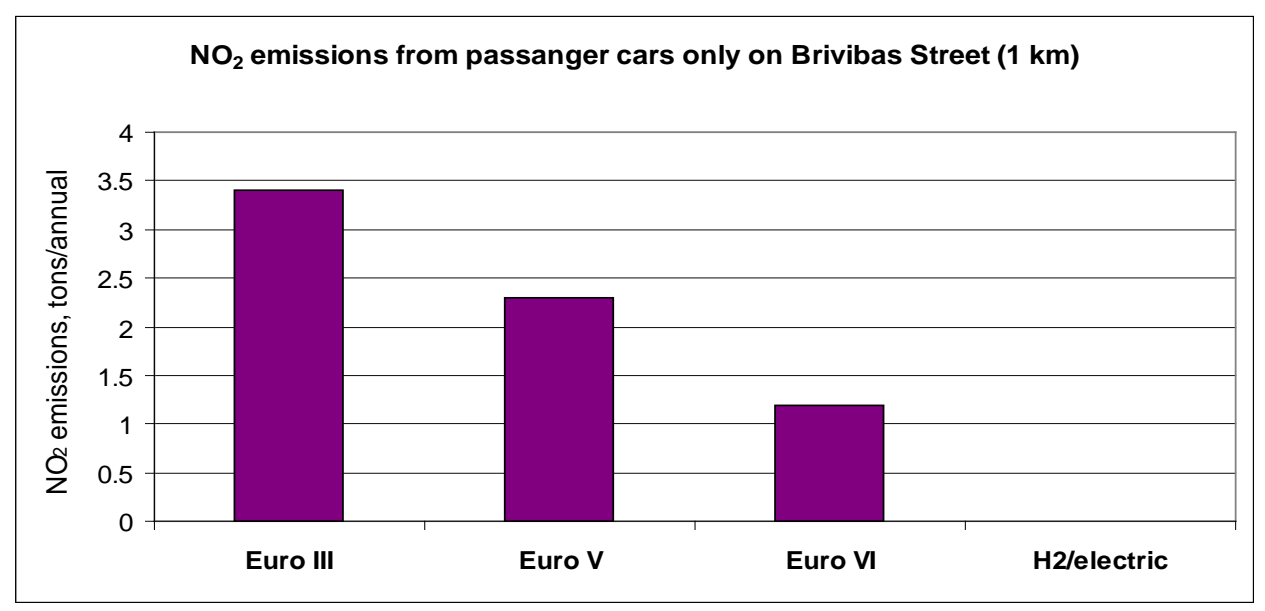

Fig. 3. Calculated annual $\mathrm{NO}_{2}$ emissions from passenger cars driving $1 \mathrm{~km}$ on Brīvības Street, Riga, 2011-2015.

In 2009 the results of the first Activity Program in Riga to improve air quality (2004-2009) were evaluated (Kleperis et al., 2011; EU Roadmap, 2011; TEN-T Days, 2015), and it was concluded that the taken measures to reduce emissions from 
traffic were not effective enough to ensure that the established air quality limit values are complied with.

The most significant potential measures in the second Activity Program (20112015) (Riga City Council City Development Department, 2011) were the reduction of traffic intensity in the city and improvement of quality of vehicles. It was possible by implementing large infrastructure projects, for example, the average number of vehicles daily crossing three bridges of Riga decreased significantly, when the new Dienvidu Bridge was opened in 2009 (Fig. 4): on Salu Bridge - by 26 \%, Vansu Bridge - by $10 \%$, Akmens Bridge - by $8 \%$. This should be taken into account in medium and long-term planning.

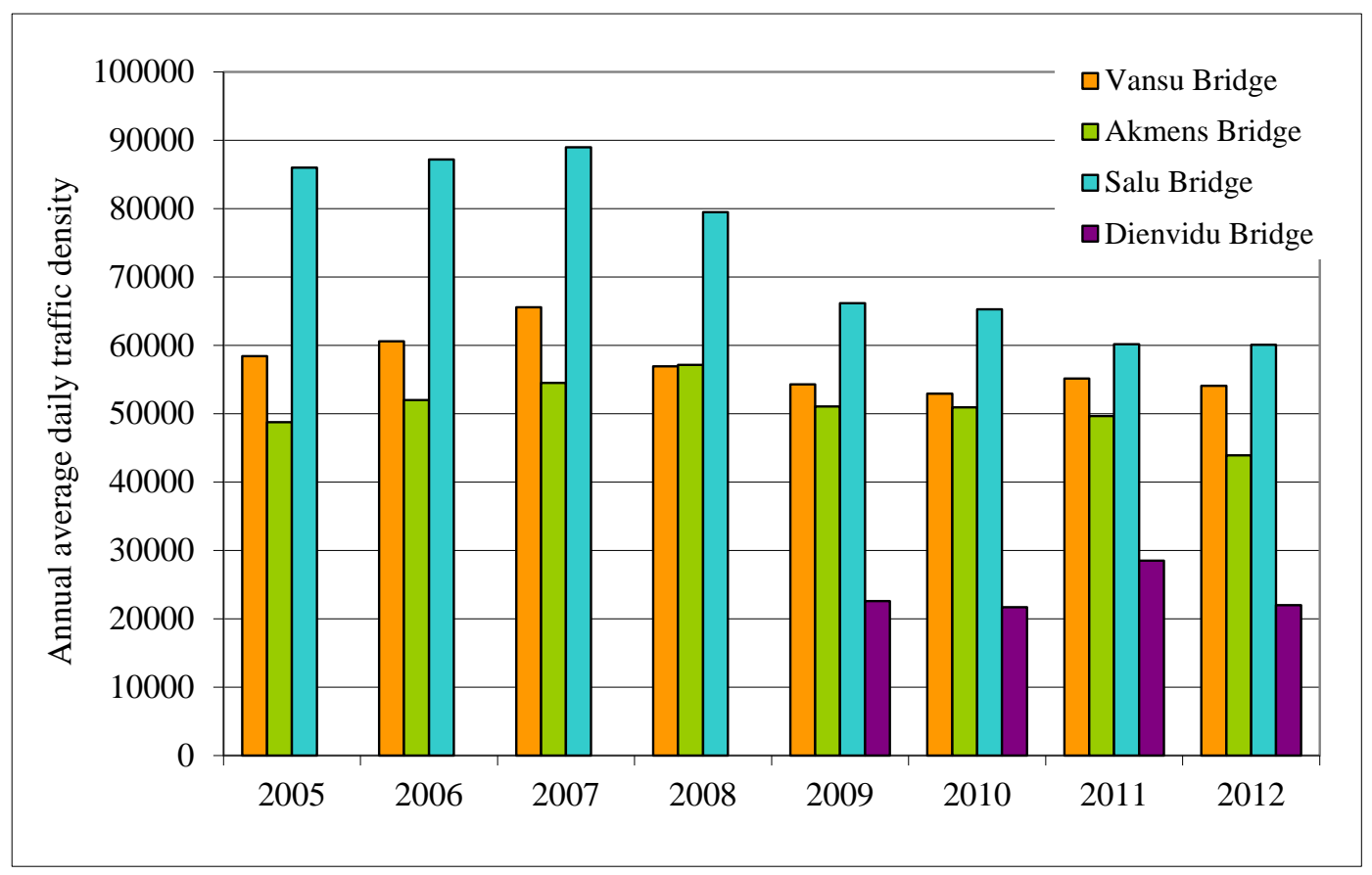

Fig. 4. Number of annual average daily traffic on bridges across the River Daugava in Riga (Dienvidu Bridge is the newest one and was opened in 2009).

To decrease traffic intensity in the city centre, strictly restrictive measures were introduced in Stockholm (rush hour taxes), in London (low emission zones), which are socially and politically sensitive. Riga is implementing large traffic infrastructure projects, for example, Austrumu trunk road to Sea Port, Brīvības Street substitute road, the North crossing of River Daugava etc., however they are time-consuming (Ministry of Transport Republic of Latvia, 2010).

\section{ENERGY RESOURCES IN LATVIA}

Latvia is one of the EU countries that strongly depend on imported energy resources. The most significant local energy resources used are fuel-wood and hydro-energy (3 large hydro-energy power plants on river Daugava with total energy capacity of $1535.5 \mathrm{MW}_{\mathrm{el}}$, and 143 small plants on small rivers) (Ministry of 
Economics of the Republic of Latvia, 2011). Part of electricity is generated by Latvian hydro power plants (HPP), combined heat and power plants (CHP), biogas and wind power plants, whereas the other part is imported. In 2011 the production of electricity reached 6093 Gigawatt hours (GWh), which is $8 \%$ less than in 2010. From renewable energy resources $50.5 \%$ of the total volume of electricity was produced (water, wind, biogas and biomass power plants). Total consumption of electric energy in 2011 in Latvia comprised $7338 \mathrm{GWh}$, which is a decrease of $2 \%$ as compared to 2010 . Consumption in industry grew by $5 \%$, while the consumption in households declined by $8.6 \%$ (data of the A/S Latvenergo). Net import of energy (difference between import and export) was $17 \%$ (12 \% in 2010) (Consumption of Energy Resources in Latvia, 2015).

The split of energy flows shows the relatively high dependence on energy import - if in electricity production it is $12-33 \%$ of total consumption, then for heat production it is 55-70 \%, and close to $99 \%$ in traffic sector (Hoffmann, 2012; Ministry of Economics of the Republic of Latvia, 2011). The imported fossil fuels (natural gas, coal and residual fuel oil) and local fuels (fuel-wood) are used in electricity and heat generation (Ministry of Economics of the Republic of Latvia, 2011). If solid fuel, oil products and electricity are imported from several countries and supply regions, natural gas is imported only by one supplier - Russia. The large part of the fuel for the centralized heat supply to regions and cities are imported (coal, coke, oil products, natural gas, electricity, etc.) and only about $30 \%$ are local resources (used tires, municipal waste for heating, peat, fuel-wood, charcoal, straw, wood, biogas, bioethanol, biodiesel, hydropower, wind energy). The share of imported fossil fuels in transport sector is growing year by year and was above $99 \%$ in 2015. As it is seen from fossil fuel consumption data in the Republic of Latvia, collected by The State Revenue Service of the Republic of Latvia (Consumption of Energy Sources, 2015), from 2010 gasoline is mostly substituted by bio-gasoline, and propane-gas (LPG) consumption increased twice (Table 1). While the data of Road Traffic Safety Directorate of the Republic of Latvia (Statistics of Registered Vehicles in Latvia, n.d.), indicate that the number of cars using diesel in Latvia changed from $26.7 \%$ in 2010 to $43 \%$ in 2013 mostly accounting to gasoline cars.

Table 1. Fuel consumption in Latvia in 2009-2012

\begin{tabular}{|l|l|l|l|l|}
\hline Oil products (fuels) in tons & $\mathbf{2 0 0 9}$ & $\mathbf{2 0 1 0}$ & $\mathbf{2 0 1 1}$ & $\mathbf{2 0 1 2}$ \\
\hline Gasoline & 241227 & 28154 & 19882 & 18573 \\
\hline Gasoline bio (E5) & 80347 & 260143 & 235177 & 209416 \\
\hline Diesel & 661113 & 644871 & 642993 & 674822 \\
\hline Biodiesel (100 \%) & 1179 & 1723 & 865 & 722 \\
\hline LPG & 19751 & 21544 & 27026 & 40627 \\
\hline Total & 1002438 & 954712 & 925078 & 943438 \\
\hline
\end{tabular}

Source: Information from the State Revenue Service of Republic of Latvia.

A new trend has been observed - the types of cars in Latvia are changing; the number of gasoline cars rapidly decreases while the number of diesel cars is growing (Table 1). When second-hand gasoline and diesel cars are used, exhaust 
gases have much higher emissions of secondary pollutants - aerosols, formed from fine particles (soot) and nitrogen oxides (Bahreini et al., 2012; Gordon et al., 2014; Elliott et al., 1955). When describing the existing fleet in Riga, not only its expansion has to be emphasized, but also ageing, which at the current growth rate continues to worsen. As it is shown in the statistics of registered cars in technically good condition, $72 \%$ of them are older than 13 years, which is significantly higher than the EU standards (recommended time of the car use is 5 years) and the actual EU average fleet age (9.6 years) studied from the website of the European Automobile Manufacturers Association (http://www.acea.be/about-acea) and the Road Traffic Safety Directorate of Latvia (Statistics of Registered Vehicles in Latvia, n.d.).

Switching to bio-diesel can improve Latvian statistics accordingly to $\mathrm{CO}_{2}$ reduction target for 2020 but not $\mathrm{PM}_{10}$ and $\mathrm{NO}_{2}$ concentrations measured in streets with dense traffic (McCormick et al., 2006). As can be seen from the information above, regarding energy resources, Latvia is dependent on fossil fuel import (Klavs \& Kudrenickis, 2012). It is possible to reduce the dependence on import especially in the transport sector by switching from traditional fuels of internal combustion engines - gasoline, diesel, natural gas and propane gas, to electric and electric/hydrogen vehicles, especially where electricity and hydrogen are produced from renewable energy sources (sun, wind, rivers, geothermal energy, biomass, water), which are available in Latvia.

\section{HYDROGEN IN MOBILE APPLICATIONS}

The switch to electro-mobility, including electro-hydrogen vehicles, could solve air pollution problems in Riga. E-mobility is recognized by Riga Municipality as carbon-free transport and five charging points are already operating (Electric mobility, 2012). Municipal Enterprise "Riga Traffic" and Energy Company "Latvenergo" are using commercial electric vehicles. First, experience shows that problems can arise on cold winter days (energy capacity of batteries is falling markedly), and the increase of electric charging points and number of e-cars would significantly increase uneven load on the central power grids. A good solution is the integration of hydrogen as an energy carrier into electro-mobility, since hydrogen can be produced from domestic resources using grid energy in moments when consumption is minimal. Latvian Hydrogen Association (LHA) together with Riga Energy Agency organized a conference in Riga City Council on hydrogen for local energy and transport for politicians, government officers and society inviting lecturers from the University of Latvia and representatives from Hydrogen Fuel Cells and Electro-mobility in European Regions (HyER) (Fuel Cell Technologies, 2015). Currently in Riga City Council the first negotiations are initiated on introducing the hydrogen vehicles in the public transport of city, thus following the examples of European cities such as Berlin, Copenhagen, London, Oslo and others. Negotiations have been initiated by LHA, which called upon one of the largest fuel cell companies in the world and already recognized by Riga international public transport manufacturers. On 17-20 October 2013, international exhibition "Energy and Environment" took place in Riga, where there were several presentations on hydrogen transport experience, as well as the demonstration of hydrogen car which operated in Riga streets, and hydrogen bus was taking passengers to the exhibition 
from the city centre. Also, in 2013, the Energy Agency of Riga invited representatives from LHA to become Experts of the Advisory Council of Riga City Mayor on hydrogen technologies, and the Riga City joined HyER cities introducing hydrogen transport (FuelCellsWorks, 2013) press release of Riga City Council, 2013). Riga Energy Agency and Municipal Enterprises "Rīgas Satiksme” and "Rīgas Siltums" are supporting future implementation of FCH in public traffic and stationary co-generation. It would be wise to link hydrogen technologies in transport with electric mobility - the mileage enlarger of electric vehicles, and in stationary application - with tri-generation (sustainable production of heat/electricity/hydrogen for refueling of vehicles).

As one of the steps of implementing the strategic documents of 2014, cooperation with leading zero emission technology industry has been initiated. It includes the signing of a letter of intent for hydrogen fuel cell development and use of trolley program "Hy-Trolley" in Riga (Ballard in Euro Trolley bus deal, 2014). The enterprise "Rīgas Satiksme" as the city of Riga public transport operator, "Ballard Power Systems" (Canada) and the leading Czech trolleybus and tram manufacturer "Skoda Electrics" agreed that, in accordance with the "Hy-Trolley" program, by 2016, "Skoda” and "Ballard” plan to replace part of the Riga trolleybus traction power-generating backup diesel generators with "Ballard" - a new generation of fuel cell modules. "Ballard" takes a number of "Hy-Trolley" program project management responsibilities. The uptake of fuel cell cars, zero emission vehicles that run on electricity powered by hydrogen, depends on the availability of refueling infrastructure on the main European roads. Fuel cell electric buses will ensure green urban public transport as they offer all advantages of electric vehicles: zero tailpipe emissions, significantly reduced noise and vibration levels and, therefore, higher passenger comfort while presenting the same degree of operational flexibility as conventional diesel buses (due to comparatively long ranges and a low refueling time). HIT 2 Corridors project is the second part of a larger action aiming to establish a network of European hydrogen infrastructure for transport and to enable long distance travel with fuel cell cars. Regional implementation plan for Riga (Latvia) is being developed in frame of HIT 2 Corridors project as well as deploy and test of one hydrogen refueling station in one Public Traffic Park of Riga. As most potential hydrogen resource the biogas from waste water treatment plant is considered.

\section{RESEARCH OF PUBLIC ATTITUDE TO HYDROGEN IN LATVIA}

Before introducing new technology in Latvia it is important to research public opinion in the regions and municipalities which will be the first in implementation of demonstration projects and early market fuel cell and hydrogen infrastructure installations. The research on public opinion, and knowledge and acceptance of hydrogen energy has been performed in many countries. The survey of public opinion was done also in Latvia during 2010-2013. Typical questions were included taking into account the experience of other countries. The selected results were referred to from the last survey performed in 2013 (Sloka et al., 2014) included 16 questions and statements which asked to evaluate in the scale from 1 to 10 (1 do not agree, 10 - fully agree). In this survey 1299 respondents in all regions of Latvia took part, 51.66 \% were female and $48.27 \%$ - male. Data (arithmetic means 
of the evaluation) in Fig. 5A indicates that in Latvia the society in general is not well informed on different aspects of hydrogen use in economy. Mostly the average evaluation of respondents was low, the most often met evaluation (mode) was the lowest possible evaluation and has reached 1, although the responses of respondents were different - with wide variety of responses indicated by different indicators of variability (range, variance, standard deviation and standard error of mean).

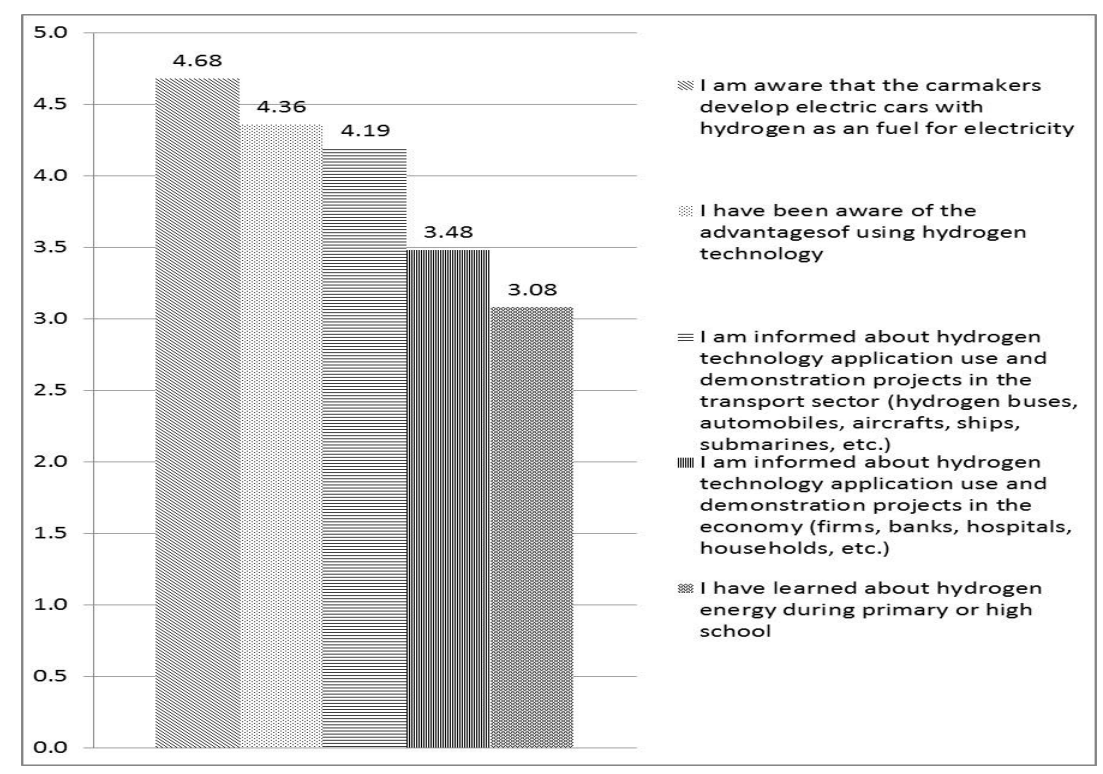

A

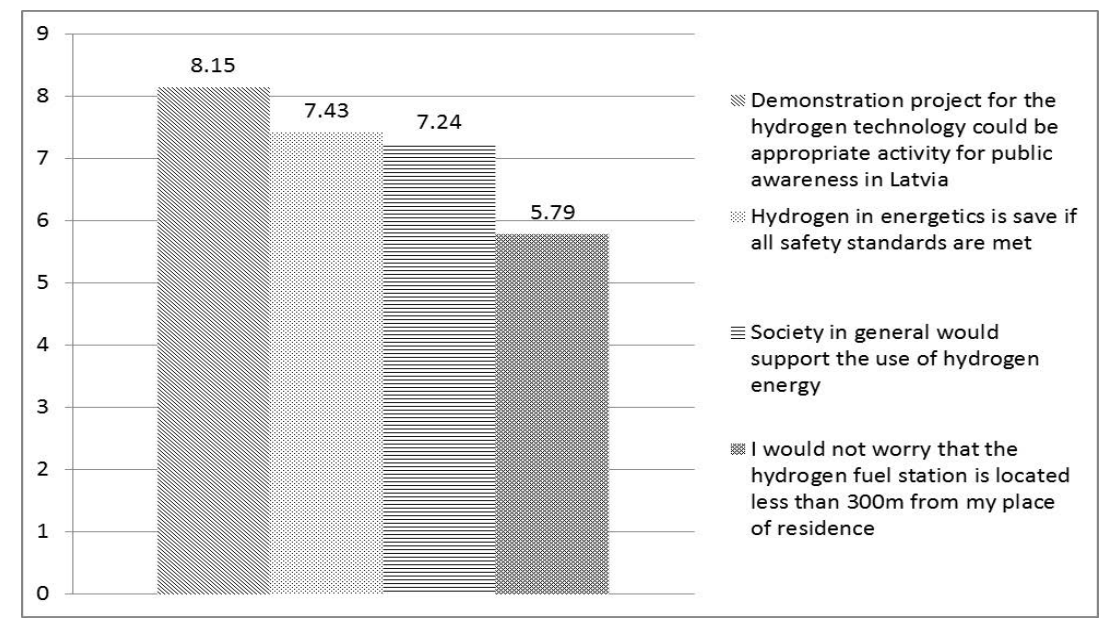

B

Fig. 5. Arithmetic mean of responses on statements on public knowledge on hydrogen in energetics (evaluation scale 1 to 10, where 1 - fully disagree, 10 - fully agree; Public survey by J. Dimants, B. Sloka, J. Kleperis, 2013, $n=1299)$.

It means that society is mostly lacking information about hydrogen energy usage in different fields of economy. The highest evaluation of respondents was to the statement "I am aware that the carmakers develop electric cars with hydrogen 
as fuel for electricity”, and it has the highest arithmetic mean of respondents' evaluation: 4.68. To this statement half of respondents gave evaluation less than 4, half of respondents gave evaluation higher than 4 (described by median). It shows that part of society has some information on hydrogen usage in cars, but information on practical use of hydrogen energy still has not reached public on reasonable level to accept hydrogen energy for practical use and more information on good applications of hydrogen energy in other countries has to be distributed on understandable and acceptable level for society. The experience of other countries in providing regular information about success stories, especially demonstration of respective devices, has to be developed.

The data in Fig. 5B shows that public support for hydrogen technology is even too large compared to the supposedly weak backgrounds. Society in Latvia in general supports the implementation of renewable energy technologies and would be interested to receive more information in media about the use of hydrogen experience in other countries. Society also in general agrees that hydrogen technology demonstration project might be a suitable activity to increase public awareness about hydrogen energy, and in general supports the introducing of hydrogen energy industry. Hydrogen safety issues have been recognized as well, though, on average, the majority of respondents totally agreed that "Hydrogen power is safe when all safety standards are met", but not so many want to have hydrogen fuel station close to their places of residence.

Such public opinion monitoring has to be organized on regular basis also in Latvia as it is already done in many developed countries.

\section{CONCLUSION}

The long-term air quality monitoring data in streets and careful analysis of the composition of fine particles proved that in Riga city centre it is mainly traffic that is responsible for air pollution (60-80 \% NO $2,50-78 \% \mathrm{CO}, 40-80 \% \mathrm{PM}_{10}$ and $30-68 \%$ of all volatile organic compounds).

Comparative analysis of air monitoring and traffic fleet data allows assessing the contribution of separate transport groups in emissions of $\mathrm{NO}_{x}$ and $\mathrm{PM}_{10}$ in the city centre streets. It was found that light passenger cars are main polluters, followed by public transport and buses. Based on foreign experience in demonstration cases suggestions are made to introduce electric/hydrogen buses and cars in Riga, and first steps that have already been made are described.

Public opinion research showed that awareness of hydrogen energy in Latvia generally can be evaluated as comparatively low, but optimistic trend is that society is ready to support the implementation of renewable energy technologies and would be interested in more information about hydrogen implementation in other countries and the safety issues.

\section{ACKNOWLEDGMENT}

This work has been supported by the National Research Program within the project Energy \& Environment (LATENERGI 2014-2017) 


\section{REFERENCES}

Actina, G., Geipele, I., \& Zeltins, N. (2015). Planning and Managing Problems of Energy and Energy Efficiency at Regional and District Level in Latvia: Case Study. In 2015 International Conference on Industrial Engineering and Operations Management (IEOM) (pp. 1-7). IEEE. Hyatt Regency Dubai; United Arab Emirates; March 3-5, 2015; Category number CFP1566Z-ART; Code 112072. http://dx.doi.org/10.1109/ieom.2015.7093843

Ādamsone, L., \& Parupa, D. (2007). Air Quality Management in Riga. Ekonomika ir vadyba: aktualijos ir perspektyvos, 1(8), 5-9. ISSN 1648-9098.

Ahmed, A., Al-Amin, A. Q., Ambrose, A. F., \& Saidur, R. (2015). Hydrogen Fuel and Transport System: A Sustainable and Environmental Future. International Journal of Hydrogen Energy, 41(3), 13691380. http://dx.doi.org/10.1016/j.ijhydene.2015.11.084

Bahreini, R., Gilman, J. B., Hall, K., Holloway, J. S. S., et al. (2012). Gasoline emissions dominate over diesel in formation of secondary organic aerosol mass. Geophysical Research Letters, 39(6). http://dx.doi.org/10.1029/2011GL050718

Ballard in Euro trolley bus deal, launches bus servicing at Van Hool. (2014). Fuel Cells Bulletin, 2014(11), 2-3. http://dx.doi.org/10.1016/S1464-2859(14)70299-8

Consumption of energy resources in Latvia. (2015). The Central Statistical Bureau of Latvia (CSB), Retrieved from http://www.csb.gov.lv/en/dati/statistics-database-30501.html

Cruz, I. S., \& Katz-Gerro, T. (2015). Urban Public Transport Companies and Strategies to Promote Sustainable Consumption Practice. Journal of Cleaner Production, 1-6.

U.S. Department of Energy. (2012). Technical Plan - Education and Outreach. Multi-Year Research, Development and Demonstration Plan. Retrieved from http://energy.gov/sites/prod/files/2014/03/f10/education.pdf

Electric mobility in Riga. (n.d.). Riga Energy Agency, Report on SUM project results, 2012. Retrieved from http://www.rea.riga.lv/files/SUM_project_meeting_in_Vigo_October_2012/Riga_practice.pdf

Elliott, M. A., Nebel, G. J., \& Rounds, F. G. (1955). The Composition of Exhaust Gases from Diesel, Gasoline and Propane Powered Motor Coaches. Journal of the Air Pollution Control Association, 5(2), 103-108. http://dx.doi.org/10.1080/00966665.1955.10467686

EU Roadmap for moving to a competitive low carbon economy in 2050 (2011). EUR-Lex: Access to European Union Law. Retrieved from http://eur-lex.europa.eu/legal-content/EN/ALL/?uri=CELEX:52011DC0112

Fuel Cell Technologies Office Multi-Year Research, Development and Demonstration Plan. (2015). Retrieved from http://www1.eere.energy.gov/hydrogenandfuelcells/mypp/

FuelCellsWorks. (2013). Riga City Council explores deployment of hydrogen applications. FuelCellsWorks. Retrieved from https://fuelcellsworks.com/archives/2013/03/28/riga-city-councilexplores-deployment-of-hydrogen-applications/

Geipele, I., Staube, T., Ciemleja, G., Ekmanis, J., \& Zeltins, N. (2014). Nanotechnologies in Latvia: Commercialisation Aspect. Latvian Journal of Physics and Technical Sciences, 51(5), 40-55. http://dx.doi.org/10.2478/lpts-2014-0029

Geipele, I., Staube, T., Ciemleja, G., Geipele, S., Zeltins, N., \& Ekmanis, J. (2015). The Development and Design of Engineering Economic Indicator System for Nanotechnology Industry Product Manufacturing: A Case Study of Latvia. Latvian Journal of Physics and Technical Sciences, 52(5), 3-19. http://dx.doi.org/10.1515/lpts-2015-0024

Gordon, T. D., Presto, A. A., May, A. A., Nguyen N. T., Lipsky, E. M., Donahue, N. M., Gutierrez, A., Zhang, M., Maddox, C., Rieger, P., Cattopadhyay, S., Maldonado, H., Maricq, M. M., \& Robinson, A. L. (2014). Secondary organic aerosol formation exceeds primary particulate matter emissions for light-duty gasoline vehicles. Atmospheric Chemistry and Physics, 14, 4661-4678. http://dx.doi.org/10.5194/acp-14-4661-2014

Hoffmann, P. (2012). Tomorrow’s Energy: Hydrogen, Fuel Cells and the Prospects for a Cleaner Planet. The MIT Press. ISBN 9780262516952, 360 p.

Klavs, G., \& Kudrenickis, I. (2012). Energy Efficiency Policies and Measures in Latvia. Riga: Institute of Physical Energetics. 91 p. 
Kleperis, J., Danilane, D., Jandulina, J., \& Vitola, E. (2002). Inventory, modelling and monitoring of traffic caused air pollution in Riga. In Proceedings of 11th International Symposium "Transport and Air Pollution” (vol. 2, pp. 259-266). Graz University of Technology, Austria, 19-21 June.

Kleperis, J. (2007). The First Riga Action Program for the Improvement of Air Quality: Achievements and Challenges. In Environment And Sustainability Profile For Riga, Riga City Council, Riga Sustainability Management Centre "Agenda 21”, (pp. 13-22), Riga.

Kleperis, J., Bajars, G., Bremere, I., Menniks, M., Viksna, A., Osite, A., \& Pavlicuks, D. (2011). Air Quality in Riga and Its Improvement Options. Environmental and Climate Technologies, 7(1), 7278. http://dx.doi.org/10.2478/v10145-011-0030-2

LR Cabinet of Ministers. (2009). Regulations on air quality. Regulation No. 1290, Accepted 03.11.2009. Retrieved September 5, 2016, from http://ikumi.lv/doc.php?id=200712

Ministry of Economics of the Republic of Latvia. (2011). Latvian Energy in Figures, 40 p. Retrieved from http://www.em.gov.lv/em/2nd/?lng=en\&cat=30166

McCormick, L. R., Williams, A., Ireland, J., Brimhall, M., \& Hayes, R. R. (2006). Effects of Biodiesel Blends on Vehicle Emissions: Fiscal Year 2006 Annual Operating Plan Milestone 10.4. Milestone Report NREL/MP-540-40554 October 2006.

Ministry of Transport Republic of Latvia. (2010). Riga and Pieriga Mobility Plan final report. Riga. Retrieved from http://www.sam.gov.lv/images/modules/items/PDF/item_3008_LET106-1_050rapd-_final_report_RPMP.pdf

Near Roadway Air Pollution and Health. (n.d.). Retrieved September 5, 2016, from EPA website, https://www3.epa.gov/otaq/nearroadway.htm

Reijalt, M. (2010). Hydrogen and fuel cell education in Europe: from when? And where? To here! And now! Journal of Cleaner Production, 18(1), S112-S117. http://dx.doi.org/10.1016/j.jclepro.2010.05.017

Ricci, M., Bellaby, P., Flynn, R. (2010). Engaging the public on paths to sustainable energy: Who has to trust whom? Energy Policy, 38(6), 2633-2640. http://dx.doi.org/10.1016/j.enpol.2009.05.038

Riga City Council City Development Department. (2011). Riga City Air Quality Improvement Action Programme 2011-2015. Retrieved from http://www.rigasprojekti.lv/uploads/GaisaProgr_Brosura_EN.pdf

Riga Energy Agency. (2014). Riga Smart City: Sustainable Energy Action Plan 2014-2020. Retrieved from http://www.rea.riga.lv/files/RIGA_SMART_CITY_SEAP_2014-2020_EN.pdf

Singh, S., Jain, S., Venkateesteswaran, P. S., Tiwari, A. K., Nouni, M. R., Pandey, J. K., \& Goel, S. (2015). Hydrogen: A Sustainable Fuel for Future of the Transport Sector. Renewable and Sustainable Energy Reviews, 51, 623-633. http://dx.doi.org/10.1016/j.rser.2015.06.040

Sloka, B., Kleperis, J., Dimants, J., Dimanta, I., \& Kleperis, Jr. J. (2014). Hydrogen as Energy Source Challenges for Regions in Latvia (Results Of Public Opinion Survey). Management Theory and Studies for Rural Business and Infrastructure Development. 36(1), 147-155. http://dx.doi.org/10.15544/mts.2014.014

Statistics of Registered Vehicles in Latvia. (n.d.). Road Traffic Safety Directorate. Retrieved May 23, 2015, from http://www.csdd.lv/eng/about_csdd/

Steinberga, I., Bikshe Jr. J., Kundzins, K., Kleperis, J., \& Bikshe, J. (2013). Evaluation of Local Scale PM Pollution Levels in Typical Street Canyon in Riga. Journal of Environmental Protection, 4, 956963. http://dx.doi.org/10.4236/jep.2013.49110

Tarigan, A. K. M., \& Bayer, S. B. (2012). Temporal change analysis of public attitude, knowledge and acceptance of hydrogen vehicles in Greater Stavanger, 2006-2009. Renewable and Sustainable Energy Reviews, 16(8), 5535-5544. http://dx.doi.org/10.1016/j.rser.2012.05.045

TEN-T Days. (2015). Joint Workshop An Innovation Pipeline for Hydrogen and Fuel Cells. Riga, Latvia, Press Release, June 23, 2015.

Wüstenhagen, R., Wolsink, M., \& Bürer, M. J. (2007). Social acceptance of renewable energy innovation: An introduction to the concept. Energy Policy, 35(5), 2683-2691. http://dx.doi.org/10.1016/j.enpol.2006.12.001

Zhang, J., McCreanor, J. E., Cullinan, P., Chung, K. F., Ohman-Strickland, P., Han, I. K., Järup, J., \& Nieuwenhuijsen, M. J. (2009). Health Effects of Real-World Exposure to Diesel Exhaust in Persons with Asthma. Health Effect Institute: Research report, 138, 144 p. 


\section{AUTHORS' SHORT BIOGRAPHIES}

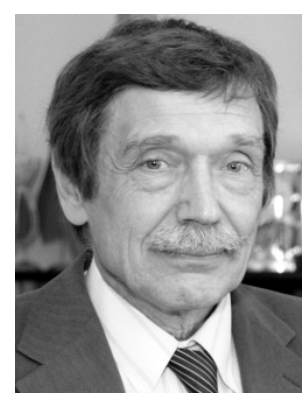

Jānis Kleperis, Dr. phys., is a Lead Researcher, Head of Laboratory of Hydrogen Energy Materials of the Institute of Solid State Physics (ISSP), University of Latvia. He has participated in various local and international projects related to materials science, energy and environment. He is an author of more than 150 scientific publications. The theme of his doctoral thesis was "Research of Colour Centres in Tungsten Trioxide". His fields of specialization are semiconductor physics, materials science, optical and electrical properties of materials, solid state ionics, electrochromic phenomena, chemical gas sensors, instruments with artificial intellect (electronic nose), hydrogen gas sensors, materials for hydrogen storage, Li and metal hydride batteries; electrolysis, membranes and MEA for fuel cells; DOAS for air pollution monitoring; air pollution measurement, emission calculations, forecasts. Jānis Kleperis is a member of International Society of Electrochemistry.

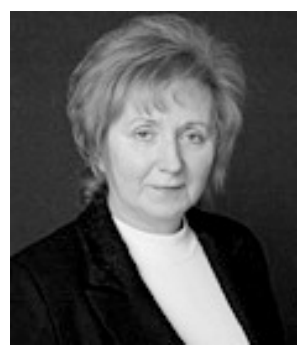

Biruta Sloka is a Professor with Faculty of Economics and Management, University of Latvia. Her research areas are marketing research, regional development and education development. She teaches the following courses: Research Methods and Organization, Recent Research Methods in Economics and Management, Marketing Research, Quantitative Methods in Marketing Research, Quantitative Methods in Decision Making, Multivariate Analysis. She is a member of Council of Faculty of Economics and Management, Council of Management Study Programs at the University of Latvia, the European Studies Program Board. She is the Chairperson of Baltic Sea Region Studies Program in the University of Latvia. She has been, Director of EuroFaculty Riga Centre (2000-2005). She is an expert in higher education quality assurance and the President of Latvian Association of Statisticians. Biruta Sloka has more than 70 scientific publications.

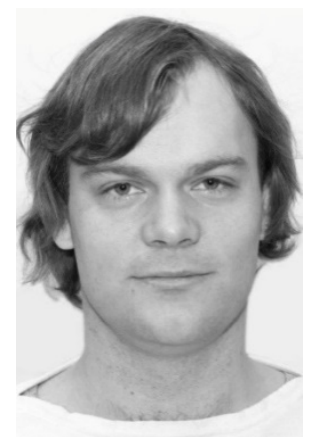

Justs Dimants received a $\mathrm{PhD}$ degree in economics (Dr. oec.) from the University of Latvia in 2013. The objective of his thesis was to evaluate the awareness of hydrogen energetics in Latvian society and to analyse the opinions of experts in the field on the possibilities of implementation and developing a marketing concept for the implementation of hydrogen energetics, taking into account international experience. Dr. Dimants is currently a researcher with the Faculty of Economics and Management of the University of Latvia, and an Engineer with the Laboratory of Hydrogen Energy Materials of Institute of Solid State Physics, University of Latvia. His main research is related to marketing implementation, legislation and policy topics of hydrogen energy.

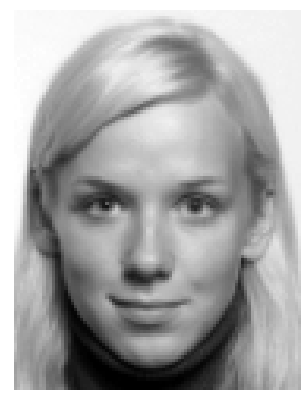

Ilze Dimanta obtained Bachelor degree, Master degree and Doctoral degree from the Faculty of Biology, the University of Latvia in 2009; 2011 and 2016, respectively. Since 2008, she has been an Assistant Researcher with the Institute of Solid State Physics, University of Latvia. Her main research fields are biohydrogen, alternative energies, biotechnology. 


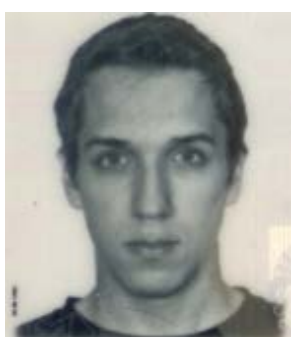

Jānis Kleperis Jr. obtained Master degree with the Faculty of Geography and Earth Sciences, University of Latvia. He has participated in the interdisciplinary (physics, biology, chemistry, economics and management) student team of the University of Latvia preparing the proposal for participation in international competition of Hydrogen Student Design Contest "Contest Combined Hydrogen, Heat and Power for a University Campus" in 2012, winning the 7th place in the world. He is currently preparing for doctoral studies. 